\title{
Erratum to: Nitrate-contaminated groundwater remediation by combined autotrophic and heterotrophic denitrification for sulfate and $\mathrm{pH}$ control: batch tests
}

Naveed Ahmed Qambrani • Sokhee Jung • Yong Sik Ok •

Yong Seong Kim • Sang-Eun Oh

Published online: 23 August 2013

(C) Springer-Verlag Berlin Heidelberg 2013

Erratum to: Environ Sci Pollut Res

DOI 10.1007/s11356-013-1623-Z

The original publication of this article contains a mistake.

The Author name Suk Hee Jung should be Sokhee Jung.

The online version of the original article can be found at http://dx.doi. org/10.1007/s11356-013-1623-z.

N. A. Qambrani · Y. S. Ok · S.-E. Oh $(\bowtie)$

Department of Biological Environment, Kangwon National

University, Chuncheon, Kangwon-do, Republic of Korea

e-mail: ohsangeun@kangwon.ac.kr

S. Jung

School of Civil and Environmental Engineering, Yonsei University,

Seoul, South Korea

\section{Y. S. Kim}

Department of Regional Infrastructure Engineering,

Kangwon National University, Chuncheon, South Korea 